Review

\title{
Systems for the delivery of chemotherapeutic drugs, new approaches and perspective
}

\author{
Halahakoon Mudiyanselage Amila Jeewantha
}

Voronezh state university, Voronezh, Russia

Received 12 December 2016, Revised 5 May 2017, Accepted 21 May 2017

C 2016, Jeewantha H.M.A.

(C) 2016, Russian Open Medical Journal

\begin{abstract}
Great perspectives in the field of drug therapy are currently associated with the targeted delivery of drugs to the organ, tissue or cells. Drug delivery systems (DDS) play a key role in enhancing the quality of chemotherapy in cancer disease. The intense interest in the topic of chemotherapy is the development of novel methods of drug delivery. The success of anti-tumor chemotherapy significantly dependends on the ability of therapeutic substances to achieve its target as well as minimal accumulation in non-specific sites (healthy organs and tissues). According to that, splendid perspectives in the field of chemotherapy are currently associated with the targeted delivery of drugs to the organs, tissues or cells. The essence of targeted delivery is that the drug itself, but more often a means of delivery systems (the vector, containers, and others.) modified by molecules, which can be identified by a unique receptor on cells or target sites. Then they are called "targeted drug delivery systems". At the same time, the engineering of multifunctional nanocarriers with several useful properties in one carrier (nanoparticles, liposomes, micelles, dendrimers, and others.) can significantly enhance the efficacy of many therapeutic and diagnostic protocols. In this article, summarize the accumulated information about potential possibilities of DDS, and the practical applications in cancer chemotherapy.
\end{abstract}

Keywords: drug delivery system, targeted drug delivery, nanocarriers

Cite as Jeewantha HMA. Systems for the delivery of chemotherapeutic drugs, new approaches and perspective. Russian Open Medical Journal 2017 ; 6: e0302.

Correspondence to Halahakoon Mudiyanselage Amila Jeewantha. Address: Department of Pharmaceutical Chemistry and Pharmaceutical Technology, Voronezh State University, 3, Studencheskya str., Voronezh, 394620, Russia. E-mail: amilajh1982@hotmail.com

\section{Introduction}

All administrating drugs (molecules or particles) before reaching their target sites have to bypass multiple biological barriers. Which barriers depend on the route of drug administration, mechanism of action and pharmaceutical formulations? Among these barriers is the reticuloendothelial system (RECs); vascular endothelium and gastrointestinal epithelial lining (transport through the cell) and the stroma (interstitial tissue) barriers; and the intersection of subcellular cell membrane and organelle. Therefore, the emerging therapeutic effect of medicines directly depends on how these drugs successfully reachtheir targets. The success of any therapeutic treatment depends not only on the pharmacokinetic/pharmacodynamic activity of the therapeutic agent but ona large extent, on its bioavailability at the site of action in the human body. Half a century ago, biopharmacy disclosed the value of the dosage forms, identifying drug formulation as the most important pharmaceutical factor influencing the therapeutic efficacy of medications. In parallel to this direction, researchers made initials attempts to create drug forms with given pharmacokinetics characteristics. Such pharmaceutical drug forms have much more complicated structure and technology in comparison with traditional drug forms; they are called therapeutic systems or drug delivery systems (DDS). The primary objectives of establishing such systems were: extended drug existence in biological fluids (longevity), the orientation of the drug actions, improvement of solubility and bioavailability, protect drugs from early biodegradation before reached to pathological sites, decreasing adverse drug reactions in healthy tissues, organs or cells, and reduced the appearance side effects. A prerequisite to the appearance of targeted drug transport was the fact that the drug administered to the organism by conventional ways was distributed there in relatively uniformly, penetrates not only the target sites, where they must show a therapeutic effect but also in other organs, tissues or cells, where the action of the drug may cause adverse effect. As a result uniform distribution of drugs, its concentration in the pathological sites can be reduced lower than the therapeutic level lead to a weak drug therapeutic effect. Prescribing higher doses of the drug for better results increases the risk of unwanted and side effects to relevant drugs (this is the main problem for most antineoplastic drugs). Transport of the drug exclusively or at least predominantly in the area covered by the pathological process can dramatically reduce adverse drug reaction, reduce the therapeutic dose of the drug and the frequency of administration. To accomplish such goals, in the present time, researchers are focusing on the nanotechnological approaches.

Nanotechnology opens up new possibilities that could not be achieved by simple methods. Nanotechnology has the potential to offer solutions to current obstacles in cancer therapies, because of its unique size and large surface-to-volume ratios. Nanotechnologies have properties of self-assembly, stability, 
specificity, drug encapsulation and biocompatibility as a result of their material composition. DDS in nanoscale $(10-1000 \mathrm{~nm})[1,2]$ or multifunctional carriers were capable of changing therapy of various diseases due to, primarily, the increased ability to overcome various biological barriers, improving half time, and targeted drug delivery $[1,3,4]$. At present, there are several nanotechnological platforms used for targeted drug delivery; they differ in physical and chemical structures $[1,5,6]$ : polymersomes, nanoparticles, nanoshells, quantum dots, nanotubes, nanoemulsion, nanoerythrosomes, dendrimers, polymeric micelle, polymer-drug conjugates and others. Also, currently pharmaceutical manufacturers are using nanomaterials not only as drugs carriers, as well as the packaging material. Thus it is possible to increase productivity and maintain drugs consumer properties. Uni- (mono), bi- or multi-laminar vesicular structures such as liposomes with a variety of desired properties can be applied as drug carriers for the anticancer drugs delivery [3, 7-10]. From the biomedical point of view, liposomes are biocompatible, cause very little or no antigenic, pyrogenic, allergic and toxic reactions; they easily undergo biodegradation. They protect the host from any undesirable effects of the encapsulated drug, at the same time protecting the entrapped drugs from the inactivating action of the physiological medium and, they are capable of delivering encapsulated contains to intracellular space in different cells. Biodistribution of liposomes is a very important parameter from the clinical point of view. These conventional liposomes in the treatment of cancer and cancer tissue encountered a serious problem of stability and inactivity of liposomes to deliver sufficient concentration at the site of tumor tissue. Also, when the pathological target site is beyond the mononuclear phagocyte system, efficient liposome uptake by the macrophages, and their subsequent removal from circulation, is one of the main disadvantages for possible use of liposomes as DDSs. In this case, some problems can be solved using novel technological approaches like nanotechnology, biotechnology, others [12, 13]. Conventional liposomes can be modified by different methods and divert into various types of liposomes with certain properties, like $\mathrm{pH}$-sensitive, thermosensitive, stealths, targeting, others. If we consider the "stealth liposomes" its suppose strongly hydrated polymer coated, covalently coupled antibodies and other protective surface proteins (serum proteins) surface, whereby such liposomes hinder macrophages do not perceive them as foreign particles to be removed. Experiments on animals had shown that therapeutic action of anticancer drugs when used "stealth liposomes" were unusually intensified and in some cases resulted in complete remission of tumors $[4,8,11]$. In malignan ttumors, a substantial decrease in the size of the metastasis was observed. Liposomes (stealth liposomes) form of the Doxorubicin (DOXIL ${ }^{\circledR}$ ) shows a significant increase in the effectiveness of treatment against the Kaposi Sarcoma [8]; Lipoplatin TM (liposomal cisplatin) shows effective reduce cisplatin neurotoxicity in phase III human clinical trials with pancreatic, head, neck, nonsmall-cell lung (NSCL) cancer patients. Also, well-known liposome technology can be applied to improve vincristine (VCR) and vinblastine (VLB) sulfate biopharmaceutical properties. For example, Jeffrey A. Silverman et al. [12] showed that the liposomal form vincristine sulfate (Marqibo ${ }^{\circledR}$ ) could overcome the doselimiting side effects of vincristine and pharmacokinetic drawbacks. Moreover, also there was scientific evidence, that polyethylene glycol (PEG) coupled liposomal surface increase the circulation half-life of liposomes [13].
Researchers focus their attention on several factors for developing new DDSs for chemotherapy. Those factors may affect therapeutic possibilities of the carrier, the enhanced permeability and retention (EPR) effect of some tumors, the ability to extravasation, intratumoral distribution, heterogeneity of tumors, overexpression of specific cell markers on the target, and others. Nowadays, researchers are used possessing research information and evidence of histological and physiological characteristics (overexpression of cell markers, EPR-effect, pH of tumor tissues, hypoxia in tumor tissues and others) most ofthe cancers types for the development of novel anticancer DDS ( $\mathrm{pH}$-sensitive, redoxsensitive, targeted and others DDS). Drug formations with targeted action (targeted drug delivery systems - TDDS) are more important for enhancing the quality of the primary cancer chemotherapy. The targeted drug delivery can be devided into two types: "active targeting" and "passive targeting" systems. The concept of passive drugs targeting was based on the EPR-effect of the tumors, the possibility to use nanocarriers for target anticancer drug delivery by the EPR - that was first proposed by Prof. Hiroshi Maeda in 1985 [14]. However, some cases show that the passive targeting method can be limited to certain types of tumors - only have no expressed with EPR-effect, also tumor blood vessels structure may not be identical in all area of the tumor. Such limitations can be overcome using programmed nanoccarries, which can selectively and actively bind with specific target cells after extravasation. It can be achieved by attaching targeting agents such as ligands molecules, to the surface of nanocarriers, which can bind to specific receptors on the cell surface via differents chemical conjugations (polymer conjugates, linkers, and others) [15-18] (see Figures 1 and 2). The concept of active direction was considered as a specific interaction between the drug carrier and the target cells, through ligand-receptor interactions. The drug carrier must be on target cells at a very close distance $(<0.5 \mathrm{~nm})$. However, these DDSs do not have selfnavigating ability to reach the target site by itself [19]. Such systems also reach the target through blood flow and extravasation. Targeted drug delivery can be also classified by areas: the system areas (systemic targeting) and intracellular direction (intracellular targeting) [17, 20-23].

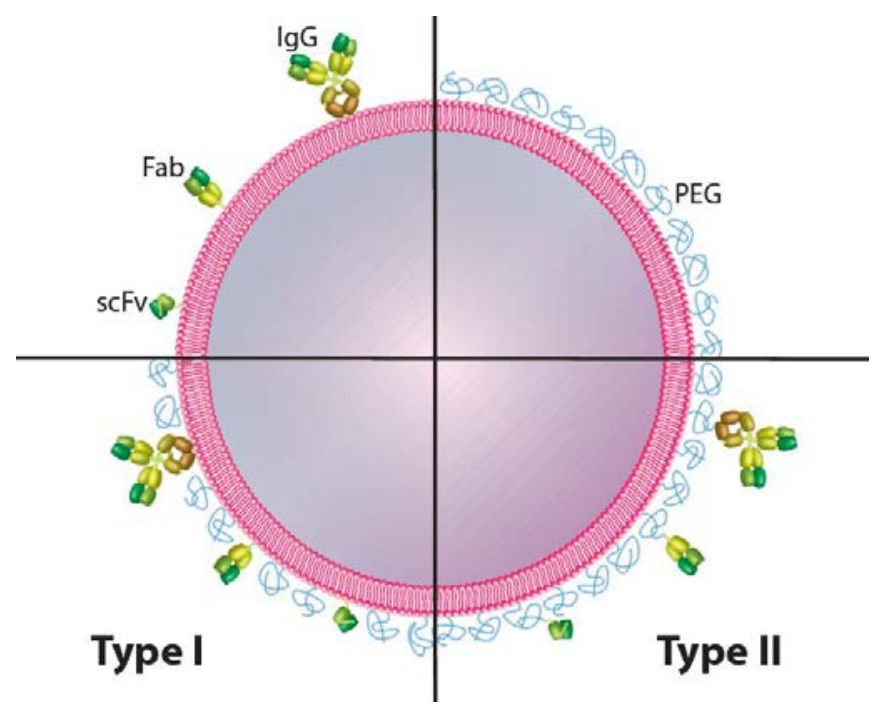

Figure 1. Schematic presentation of various kinds of immuno-liposomes. Fab - antibody; scFv - single chain Fv-fragments; PEG - polyethylene glycol. Source: http://www.liposomes.org/2011/09/ 


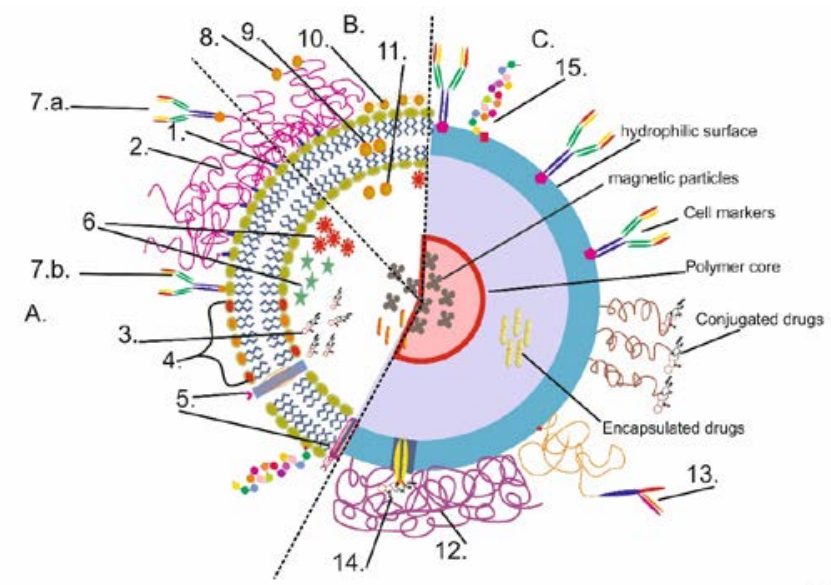

Figure 2. The schematic representation of the concept of multifunctional drug carrier.

A. Multifunctional liposome (immunoliposomes; Stealth liposomes, and others.): 1. PEG-lipid linkers; 2. Polyethylene glycol (PEG) coated "Stealth liposomes"; 3. Encapsulated Drugs; 4. Stimulus-sensitive phospholipids; 5. $\mathrm{pH}$, temperature sensitive, photo-sensible releasing receptors; 6 . Fluorescent, MRI, radiocontrast agent; 7. The targeting ligands or markers (anti-HER2 / neu, ECAMP, RGD, CD19, VEGF-A etc.) a. Connected to the distal end of the PEG-chain, b. Connected to the carrier surface.

B. Liposome-nanoparticle hybrids: 8 . Conjugated nanoparticles; 9. The nanoparticles immersed in the lipid bilayer; 10 . The nanoparticles adsorbed on the surface of liposomes; 11 . The encapsulated nanoparticles.

C. Multifunctional nanocarriers (magnetic, contrasting, $\mathrm{pH}$-sensitive, and others): 12 . $\mathrm{pH}$ or temperature sensitive polymers; 13 . The cell-specific receptors; 14 . Releasing receptors; 15 . Cells penetrating peptides are attached to the surface of carriers, and carrier absorption increases with cells.

Intracellular transport of biologically active molecules with therapeutic properties is one of the fundamental problems in drug delivery in general. Many pharmaceutical agents should be delivered intracellularly to exert their therapeutic action inside the cytoplasm or to the nucleus or other specific organelles, such as lysosomes, mitochondria, cytoskeleton, or endoplasmic reticulum. Among such agents we can find drugs that are used for gene therapy and must reach the cell nuclei; pro-apoptotic drugs to the mitochondria; lysosome enzymes to the lysosome compartment; some terpene indole alkaloids (TIAs), such as VCR and VLB, to the cytoskeleton and some others [17, 21, 24, 25]. Namely intracellular drug delivery can overcome some significant drug limitations, such as multi-drug resistance in cancer chemotherapy. In the intracellular drug delivery we can use different carriers, nanoparticles, polymeric micelles, laminar vesicles (liposomes, immunoliposomes), dendrimers, quantum dots, and others $[3,10$, 21, 26-29].

Antibodies TDDSs are the appropriate approach for the targeted delivery of anticancer therapeutic agents. By this time, scientists are considering the possibility of applying overexpression cell marker on the cell surface for the TDDSs $[26,30]$. The term overexpression is only a relative concept - between the expression level of cellular markers in target cells and normal cells. For example, in the breast, and ovarian cancer, markers of human epidermal growth factor receptor-2 (HER2) increase expression of $20-30 \%$ more than in the normal cells [31] (but some other authors claim this overexpression can vary between $10-34 \%$ [32] and $20-30 \%[26,33])$. In laboratory studies it was shown, that the increment of the HER2 has a direct relationship with the pathogenesis of breast cancer, it allows researchers to explore the possibility of using HER2 overexpression for developing TDDS breast cancer [34-36] in research. Two decades ago Dmitri Kirpotin et al. [37] have shown the potential of a stable anti-HER2immunoliposomes «PEG-modified phosphatidylethanolamine (PEGG-DSPE) coupled with the Fab (fragment-antigen binding) fragments of recombinant human monoclonal antibodies (Mab) against the extracellular domain of HER2/Neu» as a carrier for targeted delivery of therapeutic agents against HER2 overexpression cancer (Editor's comment: Neu is so named because it was derived from a rodent glioblastoma cell line, a type of neural tumor). Present day Tianshu Li et al. [38] in their research demonstrated the possibility of $\mathrm{pH}$-sensitive immunoliposomes for enhanced delivery of anticancer drug to ErbB2 (erythroblastic leukemia viral oncogene homolog-2) overexpressing breast cancer cells (Editor's comment: HER2 and HER2/Neu are synonyms of ErbB2). Overexpression of various receptors on the tumor cells have special for tumors structural and biochemical characteristics that physiologically distinguishes them from normal cells. Several integrin subtypes receptors, which are critical for cell adhesion, cell signaling, cell viability and motility, have shown overexpression in the cancer cells $[32,39]$. Extracellular matrix (ECM) molecules serve as ligands for integrins and are crucial for carcinogenesis. $\alpha v \beta 3$-integrin receptors are overexpressed on the surface of various cancer cells, play a critical role in the development of tumor angiogenesis $(\alpha v \beta 3, \alpha v \beta 5, \alpha 5 \beta 1)$ and metastasis of cancer cells. Thus, ligands that recognize specific subtypes of integrins seem excellent candidates for conjugation to drugs or the carrier for the tumor targeted drug delivery [40]. Many adhesive proteins present in extracellular matrices and the blood contain the tripeptide arginine-glycine-aspartic acid (RGD) as their cell recognition site. Shunrong Ji et al. [41] developed RGDconjugated albumin nanoparticles as a novel DDS for the pancreatic cancer therapy. Cell uptake studies were conducted on BXPC-3 (primary human pancreatic tumor line) cells since they overexpress $\alpha \vee \beta 3$-receptors. They showed that RGD-conjugated albumin gemcitabine-loaded nanoparticles (94-166 nm) were successfully taken up into BxPC-3 cells in a particular fashion and the in vitro and in vivo antitumor efficacy was improved against BxPC-3 cells.

Nowadays, many researchers have been able to create a variety of therapeutic systems to drugs delivery with explicitly given property (stealth liposomes, immunoliposomes, nanoparticles, micelles, others) [3, 10, 26-29, 42], which can be successfully used for the delivery of anticancer drugs. D. Kirpotin et al. [37, 43], Tao Yang et al. [33], and others, in their research, have proved the potentials of immunoliposomes application for targeted delivery of anticancer drugs (doxorubicin, vincristine, and others) in breast cancer, others. Immunoliposomes - a type of liposomes, which surface is associated with antibodies or portions of antibody (epithelial cell adhesion molecule - EpCAM, HER2/Neu, cluster of differentiation - CD5, CD19, CD20, human heparin-binding epidermal growth factor-like growth factor - HBEGF, vascular endothelial growth factor A - VEGF-A, disialoganglioside - GD2, cancer antigen 19-9 - CA19-9, mucin 1 Muc-1, platelet derived growth factor - PDGF, sulfotransferase family 2B member 1 - SULT2B1, others) [15, 17, 20, 44-52] prevailing purposeful action as a carrier for medicines. 
Immunoliposomes can be divided into 3 groups according to their structure $[53,54]$ (see Figure 1). Type I - Immunoliposomes molecules (fragment) antibodies are directly connected to the surface of the bilayer, with the absence of PEG chains (type I-a) or presence (type Ib). Type II antibodies are coupled to the distal end of the PEG chain.

The most frequently used, typical antigens belong to an antigen family of HER. In this context HER2 (membrane protein, tyrosine kinase family receptors of the epidermal factor EGFR/ErbB growth encoded by a human gene ERBB2) is most widely used in clinical trials as a target $[26,49,55]$. EpCAM is a transmembrane protein that is involved in epithelium-specific $\mathrm{Ca}^{2+}$ independent cell-cell adhesion [44, 56]. Among tumor tissue, almost all the carcinomas carry EpCAM on their surface. They showed varying degrees of expression in cervix, lung, breast, prostate, renal cell, colon, rectum, and cutaneous squamous cell carcinoma [47, 52, $56,57]$. The EpCAM expression is virtually absent in melanoma, primary central nervous system tumor, sarcoma, lymphoma, and germ cell tumors [44]. At present, researchers have developed a more advanced form of immunoliposomes that is called Lyticimmunoliposomes (LILS) [26]. Enrique et al. (48) in the research study developed Trastuzumab [58] (Herceptin ${ }^{\mathrm{TM}}$ ) encapsulated LILS against MCF7/HER2 (Editor's comment: MCF-7 is a breast cancer cell line isolated in 1970 from a 69-year-old Caucasian woman. MCF-7 is the acronym of Michigan Cancer Foundation-7, referring to the institute in Detroit where the cell line was established in 1973 by Herbert Soule and co-workers. Source: https://en.wikipedia.org/wiki/MCF-7), and SKBr3 tumor cells lines (Editor's comment: $\mathrm{SkBr} 3$ is a cell line isolated by the Memorial Sloan-Kettering Cancer Center in 1970. Source: https://en.wikipedia.org/wiki/SKBR3). In the experiment, they noticed that immunoliposomes drastically decreased the viability of the studied cell lines, which directly correlated with their level of HER2 expression. Cancer-treatment with Trastuzumab incorporated onto the immunoliposomes showed dramatically increased cell deaths with a minimum concentration level $(4.7 \mu \mathrm{g} / \mathrm{mL})$, compared to the free Trastuzumab (100 $\mu \mathrm{g} / \mathrm{mL})$. Also, they noticed that Trastuzumab incorporated onto the immunoliposomes reduced the length of the treatment and showed 20-fold higher therapeutic efficacy than free Trastuzumab. Based on the experiment carried out by Enrique et al., we can make a conclusion that HER2-targeted immunoliposomes coupled to trastuzumab exhibit specific cytotoxicity against HER2overexpressing breast cancer cells, a capacity which correlated with the level of HER2 expression at the cell membranes.

Common features of the most tumors are abnormal, deformed capillaries with permeable walls, slow blood flow, and poor lymph drainage. As a consequence, the unbound drug can diffuse not specifically, while nanocarriers may extravasate in the leaky tumor tissue through permeable capillaries by the effect of increased permeability and retention (EPR-effect) (Figure 3) [20, 36, 59, 60].

The increased permeability of blood vessels in the tumors, characterized by the rapid and defective neoangiogenesis (formation of new blood vessels from existing ones). In addition to, dysfunctional lymphatic drainage in tumors allows nanocarriers to accumulate and release their drugs in proximity to the tumor cells. In experiments, researchers used different liposome sizes and demonstrated that the threshold size of the vesicles to extravasated into the tumors was $\sim 400 \mathrm{~nm}$ (Figure 3), but some other studies have shown that the particles with diameters less than $200 \mathrm{~nm}(\mathrm{~d}<200 \mathrm{~nm})$ more efficient [4, 15-17, 19, 60-62].

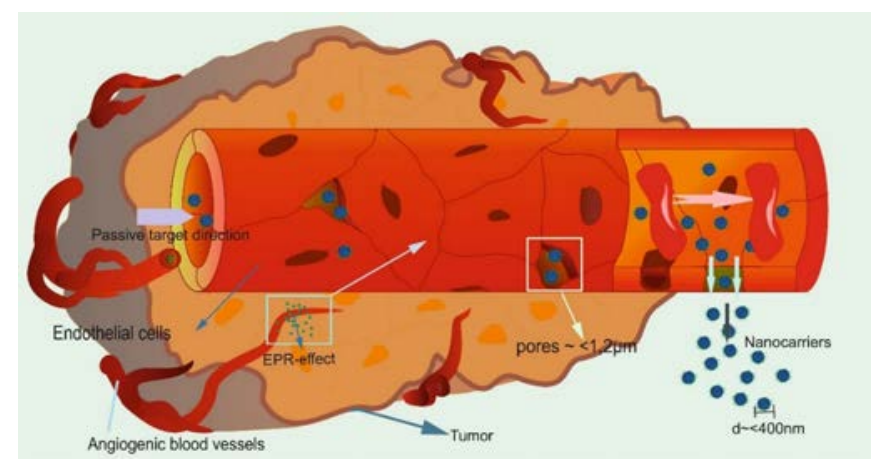

Figure 3. A schematic representation of extravasate nanocarriers through the pores of the capillary endothelium. EPR-effect is the effect enhanced permeability and retention. Neoangiogenesis in the tumor has some features. The endothelial cells of tumor vessels proliferate in several dozen times higher degree than endothelial cells of healthy vessels. As a result of high demand for nutrients, oxygen, clearance of metabolic substances, developing tumor - create a chaotic arrangement of tumor capillaries. A higher level of neoangiogenesis of tumors causes increased permeability of blood capillaries, for some solid tumors, characterized by large size pores $(\sim 1.2 \mu \mathrm{m})$ between endothelial cells in the wall of the capillaries. The pore size can be varied by the nature of the tumor, stage of development, position, place, and others.

Currently, researchers are experimenting with different approaches to suppress tumor cell growth and metastasis. In this case, there was the concept of inhibition of tumor angiogenesis, and it was achieved by oxygen and nutrients delivery limitations, metabolites elimination deficiency, which can induce suppression of proliferation and lead to the death of tumor cells. Vascular endothelial growth factor (VGEF) is one of the signaling proteins, which stimulate the process of angiogenesis [63-67]. Its numerous effects on the vascularity were shown on different types of cancer characterized by excessive expression of VGEF. For example, redundancy of VEGF often correlates with the vessel density, tortuosity, and increased microvascular permeability. Inhibition of angiogenesis in neoplastic tissues can reduce interstitial fluid pressure (IFP) within the tumors, which improves the penetration and distribution of chemotherapeutic agents into tumors $[63,67]$. Presently, some researchers made attempts to apply antiangiogenic drugs (Bevacizumab, Etoposide, Vasoatatin, others) combined with anticancer agents and showed the increase of cancer chemotherapy effectiveness [67, 68]. Sorafenib, abiraterone acetate, Tivozanib, Regorafenib are inhibitors of VEGFreceptor and are used in renal carcinoma $[65,69]$. Prostacyclin 12 (PGI2) is an important vascular prostanoid that provides an important balance in tumor angiogenesis, restores the permeability of the capillaries, pericytes (cells Rouge). Kenneth V. Honn et al. [70] first demonstrated on artificial metastasis models that PGI2 can significantly reduce the metastasis likelihood in several types of lung cancer. Yoshinori Minami et al. [17] in the research confirmed that beraprost sodium (BPS), a synthetic analog of PGI2 inhibited metastasis in cell lines of Lewis lung carcinoma in vivo.

The physiological microenvironment of solid tumors is generally characterized by insufficient perfusion and higher metabolic activity. The accumulated evidence over the past decades or more indicated that the average value of $\mathrm{pH}$ evaluation of human tumors was lower than the value of the $\mathrm{pH}$ of normal tissues [71, 72]. Wike-Hooley et al. [73] showed that this difference in is approximately 0.4 units, but some other 
researchers claim that the extracellular $\mathrm{pH}$ values are very diverse and depend on the type of tumor, method of measurement, physiology, age of the patient and others. Some researchers have considered the effect of the $\mathrm{pH}$ gradient on intratumoral tissue and healthy tissue and tried to use it for internalization drugs in the tumor and found that some chemotherapy agents have acidic or basic properties, the drugs with pKa limit of the range of 4.5-6.5 were showed significant increasing of cellular uptake by the tumor. Intracellular $\mathrm{pH}(\mathrm{pHi})$ is an important characteristic of cancer cell physiology. Cancer cells are different from normal cells in intra-extracellular $\mathrm{pH}$ gradient. Normal cells have $\mathrm{pHi}$ 7.0-7.2, while pHi of cancer cells lies in the range 7.12-7.65. Extracellular $\mathrm{pH}(\mathrm{pHe})$ of normal tissue is slightly more alkaline than $\mathrm{pHi}$ and lies in the range 7.3-7.4, while in tumor tissue it is more acidic (6.26.9) [74]. Presently, researchers made attempts to create $\mathrm{pH}$ sensitive liposomes for targeted, prolonged controlled release of drugs. The $\mathrm{pH}$-sensitive release is an attractive approach to improve the liposomes properties for the genes and drugs delivery in cancer chemotherapy.

For the preparation of $\mathrm{pH}$-sensitive liposomes [3, 11, 75-77], some researchers have used a polyacrylic acid, polyethylene glycol-ortho ester-distearoyl glycerol conjugate (POD), trans-2aminocyclohexanols [78], N-hemisuccinate-dioleoyl-phosphatidylethanolamine [79]. Nancy L. Bomane et al. [80] in the research with large unilamellar vesicle (LUV) showed that increasing the (saturated) the length of the acyl chain of phosphatidylcholine molecule increased the internal buffer capacity and made lower internal $\mathrm{pH}$; all these lead to increased drugs retention time (VCR). They proved that release half-life for vincristine from the vesicles at $370 \mathrm{C}$ in the buffer increased $1 \mathrm{~h}$ dimiristoilphosphocholine (DMPC)/Cholesterol LUV system to 12-hour diarachidoylphosphoicholine (DAPC)/dibehenoylphosphocholine (DBPC) system. This study shows that the $\mathrm{pH}$ and internal environment of the liposome can influence the release of encapsulated drugs (VCR) in vitro and in vivo, and this method can be used to prepare liposomes carrier with the controlled release and prolonged action $[75,76]$.

The achievements of nanotechnology for drug delivery as a concept have the ability to manipulate molecules and supramolecular structures for the produce devices with preprogrammed functions. Conventional liposomes, polymeric micelles, nanoemulsions [81], niosomes [82, 83] and nanoparticles are now called "nano-vehicles".

There is a tremendous opportunity to get a new drug delivery systems using nanotechnology, the benefits of nano products $[1,3$, $4,19,20,22,62,82,84-87]$ are:

i) protecting the drug from premature degradation (increases drug stability, reduces degradation and maximizes drug action) [1];

ii) preventing drugs from early interaction with the biological environment [1];

iii) increasing drug absorption in specific tissues (e.g., solid tumors) $[1,15,20]$;

iv) controling the pharmacokinetics properties of the drug and its tissue distribution $[1,15,20,22,85,88]$;

v) improving intracellular penetration $[22,28,88]$;

vi) overcome tumors multi-drug resistant (magnetic nanoparticles, immunoliposomes, nanoliposomes, etc.) [4, 19, 60, 89-91]. vii) reducing rapid excretion of some drugs, increasing the drug half-life.

The major aim of developing nanocarrier drug delivery systems is to enhance the therapeutic effect or reduce the toxicity of therapeutically active materials. In this context, nanotechnological approaches can be used to solve some problems with chemotherapeutics drugs. Ex: Paclitaxel is a poorly water-soluble anticancer molecule with a short circular period. PEGylation of paclitaxel increases the circulation time in the blood over Taxol alone. There are some studies where PEGylated nanotubes were able to prolong the circulation and significantly enhance cellular uptake of the drug by the cancer cells [92, 93]. Paclitaxel conjugated single wall PEGylated carbon nanotube showed more efficient suppressing of tumor growth in vivo than Taxol or paclitaxel-PEGconjugate in a 4T1 breast cancer animal model. Nanotubes (single wall nanotubes - SWCNTs, multiwall nanotubes - MWCNTs) are promising candidates for cancer drug delivery for multidrug resistance cancers. Functionalization of SWCNTs and MWCNTs with various conjugates (polymers, linkers, antibody, peptides, proteins, others.) can be used for developing of various multifunctional carriers for cancer therapy. Xiaoke Zhang et al. [94] developed a doxorubicin loaded modified SWCNTs with targeted and control released action. The designed carrier (DOX-FACHI/ALG-SWCNTS) demonstrated more cytotoxic effect against HeLa cell line (Editor's comment: HeLa is a cell type in an immortal cell line used in scientific research. Source: https://en.wikipedia.org/wiki/HeLa). Xiangyang Shi et al. [95] have introduced covalently attached poly-amidoamine (PAMAM) dendrimers to folic acid (FA) treated MWCNTs. Using this approach, they demonstrated that PAMAM-FA-MWCNTs can target cancer cells that overexpress FA receptors and are useful for future development of MWCNT-based platforms for targeted cancer chemotherapy, radiotherapy, and imagine purposes.

Numerous studies have shown that the liposome is a reliable carrier for the delivery of the drug to increase the therapeutic value of some anticancer drugs [46, 96-98]. In research conducted by Jeffrey A. Silverman et al., it was shown that liposomal vincristine has high plasma concentrations than free vincristine sulfate and it shows more antitumor activity. Eshan Aboutaleb et al. [99] developed a new carrier, which includes a water-soluble free vincristine sulfate in solid lipid nanoparticles with the aid of dextran sodium sulfate using a microemulsion method. Their formulation has comparable reduced cytotoxic side effects than non-encapsulated drugs for use against MDA-MB-231 cells. Eshan Aboutaleb et al. proved that the solid lipid nanoparticles of cetyl palmitate, a potential carrier for vincristine drug delivery to the brain, to increase the half-life, plasma concentration and also have highest brain tissue accumulation by administering particles via the tail vein of rats. Paola Sánchez-Moreno et al. [51] formed immuno-lipid nanocapsules for targeted delivery of anticancer drugs acting on HER2-positive cells in breast cancer. They showed the development of immuno-nanocapsules when some antibody molecules with various immuno-specificity conjugated on the nanocapsule surface efficiently absorbed by the cancer cells.

In most cases of anticancer chemotherapy, tumors develop resistance to multiple types of drugs. Multidrug resistance induced by drugs at an early administration, the cells can then develop cross-resistance to several unexposed and structurally unrelated chemotherapeutic agents. The mechanisms of multidrug resistance are: reducing the absorption of therapeutic substances, changes in cellular metabolic pathways and increasing the outflow 
of active therapeutic substances from the cells [89, 100-103]. Overexpression of ATP-binding cassette $(A B C)$ transporter is a common reason for the appearance of MDR in the tumors. $A B C$ transporters are large membrane-bind proteins composed of two nucleotide binding domains and the two transmembrane domains that are involved in active drugs transport as a mediator (substrate) of the cell. They include P-glycoprotein - a protein multidrug resistance 1 (MDR1), and others [100, 102].

Overexpression of P-glycoprotein (permeability glycoprotein «P-GP» and multidrug resistance protein 1 «MDR1») in tumor cells confers resistance to many drugs. P-GP is an important protein of the cell membrane that pumps a large number of drugs out of the cell including many broadly active cytotoxic drugs likes; Taxol ${ }^{\circledR}$, vincristine, vinblastine, actinomycin $D$, colchicine and daunorubicin use in chemotherapy. Overexpression of membrane transporter, at the blood-brain barrier (BBB), makes impediment for P-GP substrates when entering to the brain. Overexpression of P-GP in pathological tissues can make the treatment of various diseases difficult and minimize the effectiveness of P-GP substrates drugs like - anti-HIV drugs (ritonavir, saquinavir, nelfinavir), and various antitumor drugs (vincristine, vinblastine, daunorubicin, and others) [103]. Recently, researchers are actively involved in working on experiments to overcome the drug resistance of tumors. Many scientists make attempts to co-encapsulate cytotoxic agents and $P$ GP-inhibitors into nanoparticles to overcome P-GP mediated drugs efflux from the tumor cells. Decreased drug efflux will help to accumulate antitumor drugs in the tumor cells. However, application of P-GP-inhibitors (verapamil, quinidine, cyclosporin A, ginsenosides, quercetin and other flavonoids) also can limit the expecting result because of adverse effects, incompatibility and drug interaction with many of anticancer drugs. However, some researchers have been able to obtain positive results. Xiang Rong Song et al. [104] in the conducted study showed that vincristine sulfate, and verapamil GC (an inhibitor of P-GP) co-encapsulated polylactic-co-glycolic acid (PLGA) nanoparticles could improve the therapeutic effect of vincristine, and also increase bioavailability [60].

Chenyu Wang et al. [68] showed that vincristine encapsulated in PEG-associated liposomes (PEGylated-liposomes) conjugated with folic acid (FA-PEG-Ls-VCR) have an enhanced anticancer effectiveness on drug-resistant tumors and have the potential targeted action. They have demonstrated that FA-PEG-Ls-VCR form has a greater cytotoxicity than PEG-LS-VCR or free VCR. They compared the VCR concentration that causes the death of $50 \%$ tumor cel (IC50) I line KBv200. Thus, FA-PEG-Ls-VCR forms showed the lowest VCR concentration level than in the other drug forms. This research provided a very useful indication of the new way, how we can reduce a dose-limiting side effect of vincristine. Sun AX et al. [105] in research showed that the combination of tetrandrine (tetrandrine is a calcium channel blocker, is bisbenzylisoquinoline alkaloid isolated from the root of Stephania tetrandra S. Moore) with doxorubicin and vincristine in vitro demonstrate synergistic antitumor effects.

Organic anion transporter polypeptide (OATP) is sodiumindependent transmembrane mediator of the intracellular transport of clinically important drugs and hormones and allows internalization and distribution of the drug within the cell. Nowadays, it was known 11 human OATPs, and their amino acid sequences were conventionally divided into 6 groups $[7,21,101$, 106]. OATP amino acid sequences are expressing in certain schemes in healthy cells, tissues, organs, resident endothelial cells and other biological barriers, but in pathological sites, they will be overexpression and may contravene their amino acid sequences and also differ from the OATP amino acid sequences in normal cells and tissues. Scientific research data argue that the OATP1B1, OATP1B3 species De novo are expressed only in liver cells, but they were found in the states of cancer in the colon, pancreas, breast, prostate, lungs, and ovaries. Many different tumor entities show an altered expression of OATPs, and it can be used for cancer diagnostic purposes, and also a target for tumor drug delivery (tumor immunotherapy) [106].

In the research conducted by Charles O. Noble et al. [46] it was proven that liposomal form of vincristine with targeted action can only be applied, when the form is stable (immunoliposomes). For the experimental procedure, they prepared a liposomal form and nanoliposomal form of vincristine and vinblastine, the results showed that the pharmacokinetics profile of the liposomal form doesn't differ from nanoliposomal forms, but significantly increased clearance. Also In the experiment, it was shown that an immunoliposomes form of vincristine with targeted action (antiHER2 ILs-VCR) and liposomal forms without targeted action (LsVCR) have much pronounced therapeutic effect against HER2 markers overexpression xenografts of BT474-m2 in rats.

Recently, some of the researchers have made attempts to understand the possibility of applying an external magnetic field for targeted delivery of various therapeutic agents, and diagnosing agents [91, 107-112]. These studies have shown impressive results, and the ability to use it in chemotherapy, anticancer hyperthermia [113] and neutrons captured therapy (NCT). The magnetically targeted delivery of drugs (magnetic drug targeting) has been applied to increase selective delivery of chemotherapeutic agents to tumors, which reduce their accumulation in healthy tissues and associated side effects. Magnetic targeted delivery of drugs (MDT) was introduced by Kenneth J. Widder et al. [114] for specific targeting delivery of Adriamycin-loaded magnetic albumin microspheres. Magnetic liposomes and the magnetic nanoparticles have been used for a broad range of biomedical and diagnostic applications, such as determination of cell growth, magnetic resonance imaging (MRI), magnetic hyperthermia [91, 110, 112, 115, 116] and localized targeting drugs delivery $[15,85,90,91,117]$. In research conducted by Suman Dandamudi et al. [112] was shown in vivo that magnetic field improves vascular absorption of vinblastine encapsulated magnetic cationic liposomes (MCLs-VLB) in tumors and significantly increases the cytotoxic activity against B16-F10 tumor cells. At the same time, they found an alternative external magnetic field that is more efficient than a constant and significantly enhances the accumulation of MCLs-VLB in the tumor site.

The iron oxide materials are used mostly $\left(\mathrm{Fe}_{2} \mathrm{O}_{3}\right)$ as sources of magnetic nanoparticles. However, the iron oxides have several advantages over the Fe and Co nanoparticles, for example, better oxidation stability, compatibility in non-aqueous systems and the absence of toxicity. Among the four obvious crystalline polymorphic modifications of iron (III) oxide $\left(\alpha-\mathrm{Fe}_{2} \mathrm{O}_{3}\right.$ as hematite, $\beta-\mathrm{Fe}_{2} \mathrm{O}_{3}, \gamma-\mathrm{Fe}_{2} \mathrm{O}_{3}$ maghemite and a $\varepsilon-\mathrm{Fe}_{2} \mathrm{O}_{3}$ ), maghemite gained the most interest as magnetic materials $[90,110]$. Also, talking about the biocompatibility and biodegradability, magnetite $\mathrm{Fe}_{3} \mathrm{O}_{4}$ is a very promising candidate. The coating of magnetic nanoparticles with polymers is the most common method for developing a magnetic targeting drug delivery system and diagnostic tools. Moreover, it allows to improve the stability of the nanoparticles 
from oxidation in the body and may provide certain properties to the nanocarriers as thermal sensitivity (ex: poly- $\mathrm{N}$-isopropylacrylamide) [1], the $\mathrm{pH}$ sensitivity (ex: N-naphthyl-Odimethylmaleoyl chitosan, poly(2-(dimethylamine)ethyl methacrylate (PDMAEMA), polyethylene glycol-ortho esterdistearoyl glycol conjugate (POD) / dioleoylphosphatidylethanolamine (DOPE) $[76,85,118]$, targeted action, etc. Eun-Kyung Lim et al. [85] in their research created pH sensitive doxorubicin encapsulated N-naphthyl-Odimethylmaleoyl-chitosan nanoparticles for the effective treatment of tumor cells NIH3T6.7 in vivo.

Shanta Singh N et al. [119] in conducted research discovered the potential of mesoporous silicate nanoparticles (MSNs) encapsulated fluorescent nanoparticles (YVO4: $\mathrm{Eu}^{3+}$ ) and $\mathrm{Fe}_{3} \mathrm{O}_{4}$ nanoparticles as carriers for delivery of therapeutic substances. They found $\left[\mathrm{YVO}_{4}: \mathrm{Eu}^{3+}-\mathrm{MSNs}\right.$ ] encapsulated doxorubicin has synergistic cytotoxic effects against HeLa tumor cells line and MCF7, also identify the $\mathrm{pH}$ sensitive release of doxorubicin from $\left[\mathrm{YVO}_{4}\right.$ : $\mathrm{Eu}^{3+}-\mathrm{MSN}$ ]-DOX and $53 \%$ encapsulated doxorubicin release at $\mathrm{pH} 4.3$ and $31 \%$ at $\mathrm{pH}$ 7.4. In the work of Lilian Zhou et al. [22] developed a simple method for synthesis of magnetic nanoparticles (MNPS) coated with poly-2-dimethylamino-ethyl methacrylate (PDMAEMA) as a new potential carrier for targeted drug delivery with controlled-release. Ecaterina Andronescu et al. (117) in their work developed collagen/hydroxyapatite - magnetite composite material $\left(\mathrm{COLL} / \mathrm{HA}-\mathrm{Fe}_{3} \mathrm{O}_{4}\right)$ for the treatment of cancer in the bones; studies have shown prepared material has a multifunctional, regenerative effect (collagen/hydroxyapatite) and the anti-tumor effect manifested by magnetic hyperthermia. They found that more than $5 \%$ content of $\mathrm{COLL} / \mathrm{HA}-\mathrm{Fe}_{3} \mathrm{O}_{4}$ in the particle demonstrates the pronounced magnetic hyperthermal effect on tumor cells.

Yong-Xing Zhao et al. [96] in the experiment demonstrated the possibility of using DNA nanostructure (DNA-origami) as a drugs carrier; they described the possibility of using DNA-origami nanostructures as a delivery system for doxorubicin. They carried out in vitro studies and demonstrated that DNA-origamidoxorubicin system increases the intracellular penetration of doxorubicin and triggers apoptosis in cell line MCF-7, MDA-MB231 and MDA-MB-468 (breast cancer cells) at a lower concentration than the doxorubicin alone. DNA origami based construction has several advantages: (i) same size, shape, and charge for each particle instead of the size distribution often seen for self-assembled nanostructures; (ii) perfect control of the placement of functionalities on the structure using specific oligonucleotides. Such properties of DNA-origami make it a worthy candidate for developing of an ideal system for drugs delivery in chemotherapy in the future.

Batyrbekov et al. [120] in their research has shown the possibility for developing calcium alginate gel microparticles drug delivery systems for sustained release of vincristine. Researchers use different types of drugs delivery system (liposome, nanoparticles, micelles, and others) for vincristine sulfate, and vinblastine sulfate, to increase the efficiency, bioavailability and decrease side effects with the help of targeted drug delivery. Table 1 provides a summary of some of the systems were used to deliver vincristine and vinblastine and other chemotherapeutic agents.

Nanomedicine is defined as the application of nanotechnology to achieve breakthroughs in healthcare. The development of drug delivery systems has improved the therapeutic properties of existing chemotherapies and facilitated the implementation of new ones. Currently used drug delivery systems, such as liposomes, micelles, dendrimers, nanoemulsions, nanotubes, polymeric nanoparticles, quantum dots, and many others demonstrate a broad variety of useful properties. Moreover, also every one of these has own particular advantages and disadvantages in practical usage. Every day many researchers around the world try to develope novel DDS, solve existing problems associated with drug delivery. It is obvious that nanotargeted drug delivery system holds great potential to solve the problems that today's drug delivery systems are facing. It can efficiently target cells and molecules in specific areas such as inflammation and cancerous tumors, and can also help the drugs to function in an effective manner. Further research will need to be carried out to investigate the unknown properties and characteristics of the nano-drugs forms for maximum safety. A wide range of pharmacological and toxicological profiles are mandatory requirements for these DDS to practical usage. Also, it is important to understand the outcome of the drugs in the clinical usage. Another challenge is to accurately characterize molecular targets to ensure that the drug will only be released to the targeted pathological sites; this can prevent damages caused on the healthy tissues which may lead to undesirable side effects and drugs complications. Since investigating DDS increases the efficiency of drug delivery, the doses can be recalibrated. However, the future of DDS technology remains exciting and wideopen.

\section{Conclusion}

At this moment, there is a various kind of systems for the delivery of chemotherapeutic agents, and each has its advantages and disadvantages. Most of the DDS are related to synthetic nature and in the metabolic processes in the human body can produce toxic products that can cause complications and toxic effects in the elimination, and others. Therefore, it is relevant to create a more natural system for the delivery of therapeutic agents. At present, targeted delivery of chemotherapeutic agents, and drug delivery systems can completely change tactics and approaches to the treatment of cancer therapy, minimize side effects of the drugs and increase the overall effectiveness of therapy. As we review in this article, the majority of these methods, systems, and drug forms are still in the research stage, and some developed techniques gradually find their practical application in medicine and other areas. The overall goal of all these efforts - improving living conditions, the convenience of cancer patient's life, and increase the effectiveness of chemotherapy. Based on the review of published data, we can conclude that the theoretical basis of these methods will be reliable for the possibility of improving the quality of chemotherapy in the future. Still, we have to find out many answers for the existing problems in the drug delivery, step by step the researchers forwarding right direction, to where one day fulfill the Paul Ehrlich magic bullet concept.

Conflict of interest: none declared. 
Table 1. Delivery systems for some chemotherapeutics agents

\begin{tabular}{|c|c|c|c|c|c|}
\hline Type of the carrier & Authors & Forms and materials & $\begin{array}{c}\text { Encapsulated } \\
\text { agent }\end{array}$ & Size & Applications \\
\hline \multirow{5}{*}{$\begin{array}{l}\text { Poly (lactic-co- } \\
\text { glycolic acid) } \\
\text { PLGA-PEG }\end{array}$} & $\begin{array}{l}\text { Chen et al., } \\
2012[121]\end{array}$ & $\begin{array}{l}\text { Folic acid and peptide conjugated PLGA-PEG, } \\
\text { bifunctional nanoparticles }\end{array}$ & Vincristine & $\sim 250 \mathrm{~nm}$ & MCF-7 cell \\
\hline & $\begin{array}{l}\text { Ling et al., } 2010 \\
{[122]}\end{array}$ & Dextran sulfate hybrid PLGA nanoparticles & Vincristine & $\sim 128 \mathrm{~nm}$ & $\begin{array}{l}\text { MCF-7 / ADR (breast } \\
\text { cancer cell model } \\
\text { MDR) }\end{array}$ \\
\hline & $\begin{array}{l}\text { Peng Zhang et } \\
\text { al., } 2011[42]\end{array}$ & Multifunction PLGA-PEG-PS- Nanostructure & Vincristine & $\sim 95 \mathrm{~nm}$ & MCF-7/ADR \\
\hline & $\begin{array}{l}\text { Cui et al., } 2011 \\
{[123]}\end{array}$ & $\begin{array}{l}\text { Distearoyl phosphatidylethanolamine-PEG-liposomes } \\
\text { (DSPE-PEG) }\end{array}$ & Vincristine & $\sim 100 \mathrm{~nm}$ & $\begin{array}{l}\text { RM-1 prostate } \\
\text { cancer cells; DBA / } 2 \\
\text { mice; BDF1 mice }\end{array}$ \\
\hline & $\begin{array}{l}\text { Aboutalb et al., } \\
2013 \text { [99] }\end{array}$ & Dextran sulfate-solid lipid nanoparticle complex & Vincristine & $100 \sim 169 \mathrm{~nm}$ & MCF-7 \\
\hline \multirow[t]{9}{*}{ Liposomes } & $\begin{array}{l}\text { Krishna et al., } \\
2001[98]\end{array}$ & $\begin{array}{l}\text { 1,2 distearoyl-sn-glycero-3- } \\
\text { phosphocholine/cholesterol (DSPC/Chol.) or } \\
\text { sphingomyelin/ cholesterol (55/45; } \mathrm{mol} / \mathrm{mol})\end{array}$ & Vincristine & $100-120 \mathrm{~nm}$ & BDF1 mice/ LLC cells \\
\hline & $\begin{array}{l}\text { Silverman et al., } \\
2013[12]\end{array}$ & $\begin{array}{l}\text { vincristine sulfate liposome injection (Marqibo }{ }^{\circledR} \text { ), } \\
\text { sphingomyelin / cholesterol (SM / Chol.) liposomes }\end{array}$ & Vincristine & $\sim 100 \mathrm{~nm}$ & $\begin{array}{l}\text { Rag2M mice; non- } \\
\text { Hodgkin's } \\
\text { lymphoma, FDA } \\
\text { approved clinical use }\end{array}$ \\
\hline & $\begin{array}{l}\text { Zucker et al., } \\
2012[124]\end{array}$ & Phospholipon 100H / cholesterol / PEG 2000 & Vincristine & $110 \sim 130 \mathrm{~nm}$ & mice \\
\hline & $\begin{array}{l}\text { Leonetti et al., } \\
2004[125]\end{array}$ & Sphingomyelin/cholesterol liposome (SM / Chol.) & Vincristine & $\sim 115 \pm 25 \mathrm{~nm}$ & $\begin{array}{l}\text { P388 tumor cells in } \\
\text { mice and human } \\
\text { neoplastic cells A431 }\end{array}$ \\
\hline & $\begin{array}{l}\text { Mayer et al., } \\
1985[96,97]\end{array}$ & Distearoyl phosphatidylcholine (DSPC) / Cholesterol & Vincristine & $0.1 \sim 2 \mu \mathrm{m}$ & $\begin{array}{l}\text { L1210 leukemia cells } \\
\text { in mice }\end{array}$ \\
\hline & $\begin{array}{l}\text { Wong et al., } \\
2011[126]\end{array}$ & $\begin{array}{l}\text { Egg sphingomyelin (the ESM) / Cholesterol / PEG2000- } \\
\text { ceramides / quercetin (72.5: 17.5: 5: 5) liposomes. }\end{array}$ & Vincristine & $\sim 130 \mathrm{~nm}$ & cell MDA-MB-231 \\
\hline & $\begin{array}{l}\text { Wang et al., } \\
2013 \text { [89] }\end{array}$ & HSPC/Cholesterol/mPEG2000-DSPE/FA-PEG3350-DSPE & Vincristine & $79-92 \mathrm{~nm}$ & KBv200 cells \\
\hline & $\begin{array}{l}\text { Gilead Sciences } \\
\text { Inc., } 1996\end{array}$ & Distearoylphosphatidylcholine/ cholesterol 2:1 & $\begin{array}{c}\text { DaunoXome }{ }^{\circledR} \\
\text { (daunorubicin } \\
\text { citrate) }\end{array}$ & $\sim 46 \mathrm{~nm}$ & Clinical approved \\
\hline & $\begin{array}{l}\text { Stathopoulos et } \\
\text { al., } 2011[127, \\
128]\end{array}$ & $\begin{array}{l}\text { Dipalmitoylphosphatidylglycerol } \\
\text { (DPPG)/soyphosphatidyl choline (SPC-3), cholesterol/ } \\
\text { methoxypolythylene glycol distearoyl } \\
\text { phosphatidylethanolamine (m-PEG 2000-DSPE). }\end{array}$ & $\begin{array}{l}\text { Lipoplatin }^{\mathrm{TM}} \\
\text { (Cisplatin) }\end{array}$ & $\sim 110 \mathrm{~nm}$ & Phase III clinical test \\
\hline $\begin{array}{l}\mathrm{pH} \text { - sensitive } \\
\text { liposomes }\end{array}$ & $\begin{array}{l}\text { Mayer et al., } \\
1993[97] \\
\end{array}$ & $\begin{array}{l}\text { dirahidoil phosphocholine (DAPC) / di behenoyl } \\
\text { phosphocholine (DBPC) system }\end{array}$ & Vincristin & $\sim 100 \mathrm{HM}$ & In vitro \\
\hline $\begin{array}{l}\text { pH-sensitive } \\
\text { immunoliposomes }\end{array}$ & $\begin{array}{l}\text { Li et al., } 2016 \\
{[38]}\end{array}$ & $\begin{array}{l}\text { 1,5-Dihexadecyl N, N-diglutamyl-lysyl-L-glutamate / } \\
\text { (polyethylene glycol), PEG-Fab'(ErbB2)-(GGLC) } \\
\text { liposome }\end{array}$ & Doxorubicin & $\sim 202 \pm 65 \mathrm{~nm}$ & $\begin{array}{l}\text { HCC1954 cells } \\
\text { (human breast } \\
\text { cancer cells with } \\
\text { high ErbB2 } \\
\text { expression) and } \\
\text { MDA-MB-468 } \\
\text { (human breast } \\
\text { cancer cells with low } \\
\text { ErbB2 expression) }\end{array}$ \\
\hline \multirow[t]{3}{*}{$\begin{array}{l}\text { Multifunctional } \\
\text { liposomal } \\
\text { nanocarriers }\end{array}$} & $\begin{array}{l}\text { Zhang et al., } \\
2008[129]\end{array}$ & $\begin{array}{l}\text { DSPC:Chol:PEG-DSPE:PDP-PEG-DSPE:VCR + mutant } \\
\text { soluble BAFF (tumor-specific the ligand for human B- } \\
\text { cell lymphomas) }\end{array}$ & Vincristine & $0.22 \mu \mathrm{m}$ & preclinical \\
\hline & $\begin{array}{l}\text { Tuscano et al., } \\
2010[130]\end{array}$ & $\begin{array}{l}\text { hydrogenated soy } \\
\text { phosphatidylcholine/cholesterol/mPEG2000 }\end{array}$ & Doxorubicin & & $\begin{array}{l}\text { CD22-positive } \\
\text { human Burkitt's B- } \\
\text { cell lymphoma line, } \\
\text { Raji (ATCC CCL-86), } \\
\text { Ramos (ATCC CRL- } \\
\text { 1596), and CD22- } \\
\text { negative human T- } \\
\text { cell leukemia line, } \\
\text { Jurkat (ATCC TIB- } \\
\text { 152) }\end{array}$ \\
\hline & $\begin{array}{l}\text { Noble et al., } \\
2009[46]\end{array}$ & $\begin{array}{l}\text { Anti-HER2 - immunoliposomes-[Chol.- (DSPC) - (PEG- } \\
\text { DSPE) - anti-HER2 scFvF5] }\end{array}$ & Vinblastine & $76^{\sim 102 \mathrm{~nm}}$ & BT474-M2 cells \\
\hline Emulsion & $\begin{array}{l}\text { Zhang et al., } \\
2013[131]\end{array}$ & $\begin{array}{l}\text { The submicron emulsion, VCR-oleic acid ion complex } \\
\text { (VCR-OA) }\end{array}$ & Vincristine & $145^{\sim 170} \mathrm{~nm}$ & MCF-7 cells; mice \\
\hline
\end{tabular}




\begin{tabular}{|c|c|c|c|c|c|}
\hline Type of the carrier & Authors & Forms and materials & $\begin{array}{l}\text { Encapsulated } \\
\text { agent }\end{array}$ & Size & Applications \\
\hline \multirow[t]{2}{*}{ Nanoparticles } & Tan et al., 2014 & $\begin{array}{l}\text { poly (butyl cyanoacrylate) nanoparticles externally } \\
\text { modified with Pluronic }{ }^{\circledR} \text { F127 }\end{array}$ & Vincristine & $<0.8-\mu \mathrm{m}$ & $\begin{array}{l}\text { Raji cells (cells from } \\
\text { a cultured human } \\
\text { lymphoblastoid cell } \\
\text { line derived from a } \\
\text { patient with Burkitt's } \\
\text { lymphoma). }\end{array}$ \\
\hline & $\begin{array}{l}\text { Mathew et al., } \\
2010[132]\end{array}$ & $\begin{array}{l}\text { folic acid (FA) conjugated carboxymethyl chitosan } \\
\text { coordinated to manganese doped zinc sulfide } \\
\text { quantum dot (FA-CMC-ZnS: Mn) nanoparticles }\end{array}$ & 5-Fluorouracil & $130-150 \mathrm{~nm}$ & $\begin{array}{l}\text { Breast cancer cells } \\
\text { line MCF-7 and } \\
\text { Mouse fibroblast } \\
\text { cells L929 }\end{array}$ \\
\hline Quantum dot & $\begin{array}{l}\text { Savla et al., } \\
2011[133]\end{array}$ & $\begin{array}{l}\text { pH-responsive quantum dot-mucin1 aptamer- } \\
\text { doxorubicin (QD-MUC1-DOX) conjugate for }\end{array}$ & Doxorubicin & - & $\begin{array}{l}\text { A2780/AD multidrug } \\
\text { resistant human } \\
\text { ovarian carcinoma } \\
\text { cell }\end{array}$ \\
\hline \multirow[t]{2}{*}{ Nanotubes } & $\begin{array}{l}\text { Zhang et al., } \\
2009[94]\end{array}$ & $\begin{array}{l}\text { Folic acid- Chitosan- Sodium alginate-SWNTs- } \\
\text { doxorubicin (FA-CHI/ALG-SWCNTs-Dox) }\end{array}$ & Doxorubicin & $\begin{aligned} \mathrm{L} & \geq 50 \mathrm{~mm}, \mathrm{~d} \\
& \sim 1-2 \mathrm{~nm}\end{aligned}$ & HeLa cells \\
\hline & $\begin{array}{l}\text { Shi et al., } 2009 \\
\text { [95] }\end{array}$ & $\begin{array}{l}\text { Multifunctional Dendrimer-Modified Multiwalled } \\
\text { Carbon Nanotubes (MWCNT-PAMAM-FA) }\end{array}$ & $\begin{array}{c}\text { Fluorescein } \\
\text { isothiocyanate, } \\
\text { folic acid }\end{array}$ & $\begin{array}{l}\mathrm{L} \\
\sim 100 \mathrm{~nm}, \mathrm{~d} \\
\sim 30-70 \mathrm{~nm}\end{array}$ & KB Cells \\
\hline Polymer carrier & $\begin{array}{l}\text { Šírová et al., } \\
2016[134]\end{array}$ & $\begin{array}{l}\mathrm{N} \text {-(2-hydroxypropyl)methacrylamide (HPMA) - Dox } \\
\text { conjugate }\end{array}$ & Doxorubicin & - & $\begin{array}{l}\text { EL4 lymphoma } \\
\text { tumors }\end{array}$ \\
\hline
\end{tabular}

\section{References}

1. Villiers MM de, Aramwit P, Kown GS. Nanotechnology in Drug Delivery. de Villiers MM, Aramwit $P$, Kwon GS, eds. New York, NY: Springer New York, 2009; 681 p. https://dx.doi.org/10.1007/978-0-387-77667-5

2. Hoffman AS. The origins and evolution of "controlled" drug delivery systems. J Control Release 2008; 132(3): 153-163. https://dx.doi.org/10.1016/j.jconrel.2008.08.012.

3. Weissig V. Liposomes. Methods and protocols. Volume 1: Pharmaceutical nanocarriers. In: Methods in Molecular Biology; vol. 605. Weissig V, ed. Totowa, NJ: Humana Press, 2010; 559 p. https://dx.doi.org/10.1007/978-1-60327-360-2.

4. Perche F, Torchilin VP. Recent trends in multifunctional liposomal nanocarriers for enhanced tumor targeting. J Drug Deliv 2013; 2013: 705265. https://dx.doi.org/10.1155/2013/705265.

5. Alexis F, Pridgen E, Molnar LK, Farokhzad OC. Factors affecting the clearance and biodistribution of polymeric nanoparticles. Mol Pharm 2008; 5(4): 505-515. https://dx.doi.org/10.1021/mp800051m.

6. Torchilin VP. Nanotechnology for intracellular delivery and targeting. In: Nanotechnology in Drug Delivery. de Villiers MM, Aramwit $P$, Kwon GS, eds. New York, NY: Springer New York, 2009: 313-346. https://dx.doi.org/10.1007/978-0-387-77667-5

7. Missailidis S. Anticancer-therapeutics. 1st ed. West Sussex: A John Wiley \& Sons Ltd., 2008; 410 p.

8. Gasselhuber A, Dreher MR, Rattay F, Wood BJ, Haemmerich D. Comparison of conventional chemotherapy, stealth liposomes and temperaturesensitive liposomes in a mathematical model. PLoS One 2012; 7(10): e47453. https://dx.doi.org/10.1371/journal.pone.0047453.

9. Lee $\mathrm{C}-\mathrm{T}$, Huang $\mathrm{Y}-\mathrm{W}$, Yang $\mathrm{C}-\mathrm{H}$, Huang $\mathrm{K}-\mathrm{S}$. Drug delivery systems and combination therapy by using vinca alkaloids. Curr Top Med Chem
2015
15(15):
1491-1500. https://dx.doi.org/10.2174/1568026615666150414120547.

10. Immordino ML, Dosio F, Cattel L. Stealth liposomes: review of the basic science, rationale, and clinical applications existing and potential. Int J Nanomedicine 2006; 1(3): https://www.ncbi.nlm.nih.gov/pubmed/17717971.

11. Lee $\mathrm{JH}, \mathrm{Nan} A$. Combination drug delivery approaches in metastatic breast cancer. J Drug Deliv 2012; 2012: 1-17. https://dx.doi.org/10.1155/2012/915375.

12. Silverman JA, Deitcher SR. Marqibo ${ }^{\circledR}$ (vincristine sulfate liposome injection) improves the pharmacokinetics and pharmacodynamics of vincristine. Cancer Chemother Pharmacol 2013; 71(3): 555-564. https://doi.org/10.1007/s00280-012-2042-4.

13. Allen TM, Hansen C, Martin F, Redemann C, Yau-Young A. Liposomes containing synthetic lipid derivatives of poly(ethylene glycol) show prolonged circulation half-lives in vivo. Biochim Biophys Acta 1991; 1066(1): 29-36. https://doi.org/10.1016/0005-2736(91)90246-5.

14. Maeda H, Ueda M, Morinaga T, Matsumoto T. Conjugation of poly(styrene-co-maleic acid) derivatives to the antitumor protein neocarzinostatin: pronounced improvements in pharmacological properties. J Med Chem 1985; 28(4): 455-461. https://doi.org/10.1021/im00382a012.

15. Grobmyer SR, Moudgil BM. Cancer nanotechnology: methods and protocols. In: Methods in Molecular Biology; vol. 624. Grobmyer SR, Moudgil BM, eds. Totowa, NJ: Humana Press, 2010; 396 p. https://doi.org/10.1007/978-1-60761-609-2.

16. Kobayashi $\mathrm{H}$, Watanabe $\mathrm{R}$, Choyke PL. Improving conventional enhanced permeability and retention (EPR) effects; what is the appropriate target? Theranostics 2014; 4(1): 81-89. https://doi.org/10.7150/thno.7193.

17. Minami $Y$, Sasaki T, Bochimoto H, Kawabe JI, Endo S, Hira $Y$, et al. Prostaglandin 12 analog suppresses lung metastasis by recruiting pericytes in tumor angiogenesis. Int J Oncol 2015; 46(2): 548-554. https://doi.org/10.3892/ijo.2014.2783.

18. Maruyama K, Takizawa T, Yuda T, Kennel SJ, Huang L, Iwatsuru M. Targetability of novel immunoliposomes modified with amphipathic poly(ethylene glycol) $s$ conjugated at their distal terminals to monoclonal antibodies. Biochim Biophys Acta - Biomembr 1995; 1234(1): 74-80. https://doi.org/10.1016/0005-2736(94)00263-0.

19. Peer D, Karp JM, Hong S, Farokhzad OC, Margalit R, Langer R. Nanocarriers as an emerging platform for cancer therapy. Nat Nanotechnol 2007; 2(12): 751-760. https://doi.org/10.1038/nnano.2007.387.

20. Schafer-Korting M. Handbook of experimental pharmacology drug delivery. In: Handbook of Experimental Pharmacology; vol. 197. F.B. Hofmann M, J.A. Beavo, A. Busch, D. Ganten, J.-A. Karlsson, M.C. Michel, C.P. Page, W. Rosenthal, eds. Berlin, Heidelberg: Springer Berlin Heidelberg, 2010; 506 p. https://doi.org/10.1007/978-3-64200477-3.

21. Prokop A. Intracellular delivery: fundamentals and applications. In: Fundamental Biomedical Technologies; vol. 5. A. Prokop, ed. Dordrecht: Springer Netherlands, 2011; 888 p. https://doi.org/10.1007/978-94-007-1248-5. 
22. van Vlerken LE, Vyas TK, Amiji MM. Poly(ethylene glycol)-modified nanocarriers for tumor-targeted and intracellular delivery. Pharm Res 2007; 24(8): 1405-1414. https://doi.org/10.1007/s11095-007-9284-6.

23. Choi $\mathrm{YH}$, Yoo K-P, Kim J. Supercritical fluid extraction and liquid chromatography-electrospray mass analysis of vinblastine from Catharanthus roseus. Chem Pharm Bull (Tokyo) 2002; 50(9): 12941296. https://doi.org/10.1248/cpb.50.1294.

24. Narang AS, Mahato RI. Targeted delivery of small and macromolecular drugs. Boca Raton, FL: CRC Press, 2010; 629 p.

25. Mikstacka R, Stefański T, Różański J. Tubulin-interactive stilbene derivatives as anticancer agents. Cell Mol Biol Lett 2013; 18(3): 368397. https://doi.org/10.2478/s11658-013-0094-z.

26. Catania A, Barrajón-Catalán E, Nicolosi S, Cicirata F, Micol V. Immunoliposome encapsulation increases cytotoxic activity and selectivity of curcumin and resveratrol against HER2 overexpressing human breast cancer cells. Breast Cancer Res Treat 2013; 141(1): 5565. https://doi.org/10.1007/s10549-013-2667-y.

27. Torchilin VP. Multifunctional nanocarriers. Adv Drug Deliv Rev 2006; 58(14): 1532-1555. https://doi.org/10.1016/i.addr.2006.09.009.

28. Suh J, Choy K-L, Lai SK, Suk JS, Tang BC, Prabhu S, et al. PEGylation of nanoparticles improves their cytoplasmic transport. Int J Nanomedicine 2007; 2(4): 735-741. http://www.ncbi.nlm.nih.gov/pubmed/18203439.

29. Jordan MA, Wilson L. Microtubules and actin filaments: dynamic targets for cancer chemotherapy. Curr Opin Cell Biol 1998; 10(1): 123130. https://doi.org/10.1016/S0955-0674(98)80095-1.

30. Park JW, Hong K, Kirpotin DB, Colbern G, Shalaby R, Baselga J, et al. Anti-HER2 immunoliposomes: enhanced efficacy attributable to targeted delivery. Clin Cancer Res 2002; 8(4): 1172-1181. http://www.ncbi.nlm.nih.gov/pubmed/11948130.

31. Dennis JS, Brian LJ, S.Stevan, Hank F, Virginia P, Alex D, et al. Use of chemotherapy plus a monoclonal antibody against HER2 for metastatic breast cancer that overexpresses HER2. New Eng J Med 2001; 344(11): 783-792. https://doi.org/10.1056/NEJM200103153441101.

32. Schwab M. Encyclopedia of cancer. 2nd ed. NY: Springer-Verlag Berlin Heidelberg, 2008; $3306 \mathrm{p}$

33. Yang T, Choi MK, Cui F De, Lee SJ, Chung SJ, Shim CK, et al. Antitumor effect of paclitaxel-loaded PEGylated immunoliposomes against human breast cancer cells. Pharm Res 2007; 24(12): 2402-2411. https://doi.org/10.1007/s11095-007-9425-y.

34. Ben-Kasus T, Schechter B, Sela M, Yarden Y. Cancer therapeutic antibodies come of age: Targeting minimal residual disease. $\mathrm{Mol}$ Oncol 2007; 1(1): 42-54. https://doi.org/10.1016/j.molonc.2007.01.003.

35. Bae YH. Drug targeting and tumor heterogeneity. J Control Release 2009; 133(1): 2-3. https://doi.org/10.1016/j.jconrel.2008.09.074.

36. Bae YH, Park K. Targeted drug delivery to tumors: myths, reality and possibility. J Control Release 2011; 153(3): 198-205. https://dx.doi.org/10.1016/j.jconrel.2011.06.001.

37. Kirpotin D, Park JW, Hong K, Zalipsky S, Li WL, Carter P, et al. Sterically stabilized anti-HER2 immunoliposomes: design and targeting to human breast cancer cells in vitro. Biochemistry 1997; 36(1): 66-75. https://doi.org/10.1021/bi962148u.

38. Li T, Amari T, Semba K, Yamamoto T, Takeoka S. Construction and evaluation of $\mathrm{pH}$-sensitive immunoliposomes for enhanced delivery of anticancer drug to ErbB2 over-expressing breast cancer cells. Nanomedicine 2017; 13(3): 1219-1227. https://doi.org/10.1016/i.nano.2016.11.018.

39. Bash PA, Rao SN, Singh C, Kollman PA, Sussman F, Lehn JM, et al. New perspectives in cell adhesion: RGD and integrins. Science 1987; 238: 491-497. https://www.ncbi.nlm.nih.gov/pubmed/2821619.

40. Marelli UK, Rechenmacher F, Sobahi TRA, Mas-Moruno C, Kessler H. Tumor Targeting via Integrin Ligands. Front Oncol 2013; 3: 222. https://doi.org/10.3389/fonc.2013.00222.

41. Shunrong J, Jin X, Bo Z, Wantong Y, Wenyan X, Wenzhe W, et al. RGDconjugated albumin nanoparticles as a novel delivery vehicle in pancreatic cancer therapy. Cancer Biol Ther 2012; 13(4): 206-215. https://doi.org/10.4161/cbt.13.4.18692.

42. Zhang $P$, Ling $G$, Sun J, Zhang $T$, Yuan $Y$, Sun $Y$, et al. Multifunctional nanoassemblies for vincristine sulfate delivery to overcome multidrug resistance by escaping P-glycoprotein mediated efflux. Biomaterials 2011; 32(23): 5524-5533. https://doi.org/10.1016/i.biomaterials.2011.04.022.

43. Kirpotin DB. Antibody targeting of long-circulating lipidic nanoparticles does not increase tumor localization but does increase internalization in animal models. Cancer Res 2006; 66(13): 6732-6740. https://doi.org/10.1158/0008-5472.CAN-05-4199.

44. Armstrong A, Eck SL. EpCAM: a new therapeutic target for an old cancer antigen. Cancer Biol Ther 2003; 2(4): 320-325. https://doi.org/10.4161/cbt.2.4.451.

45. Chen W, Zhou H, Ye L, Zhan B. Overexpression of SULT2B1b promotes angiogenesis in human gastric cancer. Cell Physiol Biochem 2016; 38(3): 1040-1054. https://doi.org/10.1159/000443055.

46. Noble CO, Guo Z, Hayes ME, Marks JD, Park JW, Benz CC, et al. Characterization of highly stable liposomal and immunoliposomal formulations of vincristine and vinblastine. Cancer Chemother Pharmacol 2009; 64(4): 741-751. https://doi.org/10.1007/s00280008-0923-3.

47. Barrajon-Catalan $E$, Menéndez-Gutiérre $M P$, Falco $A$, Saceda $M$, Catania A, Micol V. Immunoliposomes: a multipurpose strategy in breast cancer targeted therapy. In: Breast cancer - current and alternative therapeutic modalities. P.E. Gunduz, ed. InTech; 2011: 435-452. https://doi.org/10.5772/23998.

48. Barrajón-Catalán $E$, Menéndez-Gutiérrez $M P$, Falco $A$, Carrato $A$, Saceda M, Micol V. Selective death of human breast cancer cells by Iytic immunoliposomes: correlation with their HER2 expression level. Cancer Lett 2010; 290(2): 192-203. https://doi.org/10.1016/j.canlet.2009.09.010.

49. Androutsopoulos G, Michail G, Adonakis G, Decavalas G. ErbB receptors and ErbB targeted therapies in endometrial cancer. J Cancer Ther 2014; 5(6): 483-492. https://dx.doi.org/10.4236/jct.2014.56055.

50. Drbohlavova J, Hardy R, Adam V, Kizek R, Schneeweiss O, Hubalek J. Preparation and properties of various magnetic nanoparticles. Sensors 2009; 9(4): 2352-2362. https://dx.doi.org/10.3390/s90402352.

51. Sánchez-Moreno $P$, Ortega-Vinuesa JL, Boulaiz $H$, Marchal JA, PeulaGarcía JM. Synthesis and characterization of lipid immunonanocapsules for directed drug delivery: Selective antitumor activity against HER2 positive breast-cancer cells. Biomacromolecules 2013; 14(12): 4248-4259. https://doi.org/10.1021/bm401103t.

52. Braun S, Hepp F, Kentenich CRM, Janni W, Pantel K, Riethmüller G, et al. Monoclonal antibody therapy with Edrecolomab in breast cancer patients: Monitoring of elimination of disseminated cytokeratinpositive tumor cells in bone marrow. Clin Cancer Res 1999; 5(12): 3999-4004. https://www.ncbi.nlm.nih.gov/pubmed/10632331.

53. Stewart DJ, Johnson C, Lopez A, Glisson B, Rhee JM, Bekele BN. Extensive disease small cell lung cancer dose-response relationships: implications for resistance mechanisms. J Thorac Oncol 2010; 5(11): 1826-1834. https://dx.doi.org/10.1097/JTO.0b013e3181f387c7.

54. Nandini D, Jennifer C, Brian L, Pradip D. T-DM1: a giant step forwards in HER2 therapeutics. Cancer Ther 2013; 9: 45-54.

55. Olayioye MA, Neve RM, Lane HA, Hynes NE. The ErbB signaling network: receptor heterodimerization in development and cancer. EMBO J 2000; 19(13): 3159-3167. https://doi.org/10.1093/emboj/19.13.3159.

56. Cimino A, Halushka M, Illei P, Wu X, Sukumar S, Argani P. Epithelial cell adhesion molecule (EpCAM) is overexpressed in breast cancer metastases. Breast Cancer Res Treat 2010; 123(3): 701-708. https://doi.org/10.1007/s10549-009-0671-z.

57. Winkler J, Martin-Killias P, Pluckthun A, Zangemeister-Wittke U. EpCAM-targeted delivery of nanocomplexed siRNA to tumor cells with designed ankyrin repeat proteins. Mol Cancer Ther 2009; 8(9): 26742683. https://dx.doi.org/10.1158/1535-7163.MCT-09-0402. 
58. Yim-im W, Sawatdichaikul O, Semsri S, Horata N, Mokmak W, Tongsima $\mathrm{S}$, et al. Computational analyses of curcuminoid analogs against kinase domain of HER2. BMC Bioinformatics 2014; 15(1): 261. https://dx.doi.org/10.1186/1471-2105-15-261.

59. Brown DM. Drug delivery systems in cancer therapy. Tumor targeting. Totowa, New Jersey: Humana Press, 2004; 402 p.

60. Acharya S, Sahoo SK. PLGA nanoparticles containing various anticancer agents and tumour delivery by EPR effect. Adv Drug Deliv Rev 2011; 63(3): 170-183. A https://dx.doi.org/10.1016/i.addr.2010.10.008.

61. Yuan F, Dellian M, Fukumura D, Leunig M, Berk DA, Torchilin VP, et al. Vascular Permeability in a human tumor xenograft: molecular size dependence and cutoff size. Nature 2004; 431(7007): 461-466. https://dx.doi.org/10.1038/nature02924.

62. Kannan RM, Pillai Perumal O, Kannan S. Cellular Interactions of Nano Drug Delivery Systems. In: Force Microscopy: Applications in Biology and Medicine. B.P. Jena, J.K.H. Hrber, eds. Hoboken, NJ, USA: John Wiley \& Sons Inc; 2006: 113-36. https://dx.doi.org/10.1002/0470007702.ch7.

63. Mac GF, Stefanini MO, Popel AS. Simulating therapeutics using multiscale models of the VEGF receptor system in cancer. In: Modeling tumor vasculature: molecular, cellular, and tissue level aspects and implications. T.L. Jackson, ed. Springer, 2013: 37-53. https://link.springer.com/chapter/10.1007\%2F978-1-4614-0052-3_2.

64. Li WW, Li VW, Hutnik M, Chiou AS. Tumor angiogenesis as a target for dietary cancer prevention. J Oncol 2012; 2012: 1-23. https://dx.doi.org/10.1155/2012/879623.

65. Lara JPN, Jonasch E. Kidney cancer. Berlin, Heidelberg: Springer Berlin Heidelberg, 2012; 305 p. https://dx.doi.org/10.1007/978-3-642-21858-3.

66. Roskoski R Jr. Vascular endothelial growth factor (VEGF) signaling in tumor progression. Crit Rev Oncol Hematol 2007; 62(3): 179-213. https://doi.org/10.1016/j.critrevonc.2007.01.006.

67. Kerbel RS. Tumor angiogenesis: past, present and the near future. Carcinogenesis 2000; 21(3): 505-515. https://dx.doi.org/10.1093/carcin/21.3.505.

68. Wu HC, Chang DK. Peptide-mediated liposomal drug delivery system targeting tumor blood vessels in anticancer therapy. J Oncol 2010; 2010: 723798. https://doi.org/10.1155/2010/723798.

69. Hepgur M, Sadeghi S, Dorff TB, Quinn DI. Tivozanib in the treatment of renal cell carcinoma. Biologics 2013; 7: 139-148. https://dx.doi.org/10.2147/btt.s32958.

70. Honn K V. Inhibition of tumor cell metastasis by modulation of the vascular prostacyclin/thromboxane A2 system. Clin Exp Metastasis 1983; 1(2): 103-114. https://dx.doi.org/10.1007/BF00121490.

71. Gerweck LE, Seetharaman K. Cellular pH gradient in tumor versus normal tissue: potential exploitation for the treatment of cancer. Cancer Res 1996; 56: 1194-1198. https://www.ncbi.nlm.nih.gov/pubmed/8640796.

72. Zhang $X$, Lin Y, Gillies RJ. Tumor pH and its measurement. J Nucl Med 2010; 51(8): 1167-1170. https://dx.doi.org/10.2967/jnumed.109.068981.

73. Scholz N. The relevance of crowdfunding. In: Radiotherapy and oncology. Wiesbaden: Springer Fachmedien Wiesbaden, 2015: 343366. https://dx.doi.org/10.1007/978-3-658-09837-7.

74. Druzhkova I, Shirmanova M, Lukina M, Dudenkova V, Sergeeva T, Belousov $\mathrm{V}$, et al. Registration of intracellular $\mathrm{pH}$ in cancer cells with genetically encoded ratiometric sensor. Proc SPIE, Clinical and Biomedical Spectroscopy and Imaging IV 2015; 9537: 953710. https://dx.doi.org/10.1117/12.2184756.

75. Sudimack JJ, Guo W, Tjarks W, Lee RJ. A novel pH-sensitive liposome formulation containing oleyl alcohol. Biochim Biophys Acta Biomembr 2002; 1564(1): 31-37. https://dx.doi.org/10.1016/S00052736(02)00399-1.

76. Karanth H, Murthy RSR. pH-Sensitive liposomes-principle and application in cancer therapy. J Pharm Pharmacol 2007; 59(4): 469483. https://dx.doi.org/10.1211/jpp.59.4.0001.

77. Simões $S$, Moreira JN, Fonseca $C$, Düzgüneş $N$, de Lima MCP. On the formulation of $\mathrm{pH}$-sensitive liposomes with long circulation times. $\mathrm{Adv}$
Drug Deliv Rev 2004; 56(7): 947-965. https://dx.doi.org/10.1016/j.addr.2003.10.038.

78. Samoshin V V, Brazdova B, Chertkov VA, Gremyachinskiy DE, Shestakova AK, Dobretsova EK, et al. Trans-2-Aminocyclohexanols as pH-triggered molecular switches. Arkivoc 2005; 2005(4): 129-141. http://dx.doi.org/10.3998/ark.5550190.0006.410.

79. Nayar R, Tilcock CPS, Hope MJ, Cullis PR, Schroit AJ. NSuccinyldioleoylphosphatidylethanolamine: structural preferences in pure and mixed model membranes. Biochim Biophys Acta - Biomembr 1988; 937(C): 31-41. https://dx.doi.org/10.1016/0005-2736(88)90224-6.

80. Boman NL, Mayer LD, Cullis PR. Optimization of the retention properties of vincristine in liposomal systems. Biochim Biophys Acta Biomembr 1993; 1152(2): 253-258. https://dx.doi.org/10.1016/00052736(93)90256-Y.

81. Xu L, Pan J, Chen Q, Yu Q, Chen H, Xu H, et al. In vivo evaluation of the safety of triptolide-loaded hydrogel-thickened microemulsion. Food Chem Toxicol 2008; 46(12): 3792-3799. https://dx.doi.org/10.1016/j.fct.2008.09.065.

82. Parthasarathi G, Udupa N, Umadevi P, Pillai G. Niosome encapsulated of vincristine sulfate: improved anticancer activity with reduced toxicity in mice. J Drug Target 1994; 2(2): 173-182. https://dx.doi.org/10.3109/10611869409015907.

83. Mujoriya R, Bodla RB, Dhamande K, Singh D, Patle L. Niosomal drug delivery system: The magic bullet. J Appl Pharm Sci 2011; 1(9): 20-23. http://www.japsonline.com/admin/php/uploads/254 pdf.pdf.

84. Brewer E, Coleman J, Lowman A. Emerging technologies of polymeric nanoparticles in cancer drug delivery. J Nanomater 2011; 2011: 1-10. https://dx.doi.org/10.1155/2011/408675.

85. Lim E-K, Sajomsang W, Choi Y, Jang E, Lee H, Kang B, et al. Chitosanbased intelligent theragnosis nanocomposites enable $\mathrm{pH}$-sensitive drug release with MR-guided imaging for cancer therapy. Nanoscale Res Lett 2013; 8: 467. https://dx.doi.org/10.1186/1556-276X-8-467.

86. Lazzari S, Moscatelli D, Codari F, Salmona M, Morbidelli M, Diomede L. Colloidal stability of polymeric nanoparticles in biological fluids. J Nanoparticle Res 2012; 14(6): 920. https://dx.doi.org/10.1007/s11051012-0920-7.

87. Zu Y, Zhang $Y$, Zhao $X$, Zhang $Q$, Liu $Y$, Jiang R. Optimization of the preparation process of vinblastine sulfate (VBLS)-loaded folateconjugated bovine serum albumin (BSA) nanoparticles for tumortargeted drug delivery using response surface methodology (RSM). Int J Nanomedicine 2009; 4: 321. https://dx.doi.org/10.2147/IJN.S8501.

88. Ngan VK, Bellman K, Hill BT, Wilson L, Jordan M a. Mechanism of mitotic block and inhibition of cell proliferation by the semisynthetic Vinca alkaloids vinorelbine and its newer derivative vinflunine. Mol Pharmacol 2001; 60(1): 225-232. https://dx.doi.org/10.1124/mol.60.1.225.

89. Wang C, Feng L, Yang X, Wang F, Lu W. Folic acid-conjugated liposomal vincristine for multidrug resistant cancer therapy. Asian J Pharm Sci 2013; 8(2): 118-127. https://dx.doi.org/10.1016/j.ajps.2013.07.015.

90. Chomoucka J, Drbohlavova J, Huska D, Adam V, Kizek R, Hubalek J. Magnetic nanoparticles and targeted drug delivering. Pharmacol Res 2010; 62(2): 144-149. https://dx.doi.org/10.1016/j.phrs.2010.01.014.

91. Dobson J. Magnetic nanoparticles for drug delivery. Drug Dev Res 2006; 67(1): 55-60. https://dx.doi.org/10.1002/ddr.20067.

92. Liu Z, Chen K, Davis C, Sherlock S, Cao Q, Chen X, et al. Drug delivery with carbon nanotubes for in vivo cancer treatment. Cancer Res 2008; 68(16): 6652-6660. https://dx.doi.org/10.1158/0008-5472.CAN-081468.

93. Elhissi AMA, Ahmed W, Hassan IU, Dhanak VR, D'Emanuele A. Carbon nanotubes in cancer therapy and drug delivery. J Drug Deliv 2012; 2012: 1-10. https://dx.doi.org/10.1155/2012/837327.

94. Zhang X, Meng L, Lu Q, Fei Z, Dyson PJ. Targeted delivery and controlled release of doxorubicin to cancer cells using modified single wall carbon nanotubes. Biomaterials 2009; 30(30): 6041-6047. https://dx.doi.org/10.1016/i.biomaterials.2009.07.025. 
95. Shi X, Wang SH, Shen $M$, Antwerp ME, Chen $X$, Li C, et al. Multifunctional dendrimer-modified multiwalled carbon nanotubes: synthesis, characterization, and in vitro cancer cell targeting and imaging. Biomacromolecules 2009; 10(7): 1744-1750. https://dx.doi.org/10.1021/bm9001624.

96. Mayer LD, Bally MB, Loughrey H, Masin D, Cullis PR. Liposomal vincristine preparations which exhibit decreased drug toxicity and increased activity against murine L1210 and P388 tumors. Cancer Res 1990; 50(3): 575579. https://www.ncbi.nlm.nih.gov/pubmed/2297698.

97. Mayer LD, Nayar R, Thies RL, Boman NL, Cullis PR, Bally MB. Identification of vesicle properties that enhance the antitumour activity of liposomal vincristine against murine L1210 leukemia. Cancer Chemother Pharmacol 1993; 33(1): 17-24. http://www.ncbi.nlm.nih.gov/pubmed/8269584.

98. Krishna R, Webb MS, St. Onge G, Mayer LD. Liposomal and nonliposomal drug pharmacokinetics after administration of liposomeencapsulated vincristine and their contribution to drug tissue distribution properties. J Pharmacol Exp Ther 2001; 298(3): 12061212. https://www.ncbi.nlm.nih.gov/pubmed/11504822.

99. Aboutaleb E, Atyabi F, Khoshayand MR, Vatanara AR, Ostad SN, Kobarfard F, et al. Improved brain delivery of vincristine using dextran sulfate complex solid lipid nanoparticles: optimization and in vivo evaluation. J Biomed Mater Res A 2014; 102(7): 2125-2136. https://dx.doi.org/10.1002/jbm.a.34890.

100. Mehta K, Siddik ZH. Drug resistance in cancer cells. Springer Science and Business Media LLC, 2009; 372 p.

101. Akhdar H, Legendre C, Aninat C, More F. Anticancer drug metabolism: chemotherapy resistance and new therapeutic approaches. In: Topics on Drug Metabolism. J. Paxton, ed. Rijeka, Croatia: InTech, 2012: 137170. https://dx.doi.org/10.5772/30015.

102. Chai S, To KK, Lin G. Circumvention of multi-drug resistance of cancer cells by Chinese herbal medicines. Chin Med 2010; 5(1): 26. https://dx.doi.org/10.1186/1749-8546-5-26.

103. Bansal T, Jaggi M, Khar RK, Talegaonkar S. Emerging significance of flavonoids as P-glycoprotein inhibitors in cancer chemotherapy. J Pharm Pharm Sci 2009; 12(1): 46-78. http://www.ncbi.nlm.nih.gov/pubmed/19470292.

104. Song XR, Cai Z, Zheng Y, He G, Cui FY, Gong DQ, et al. Reversion of multidrug resistance by co-encapsulation of vincristine and verapamil in PLGA nanoparticles. Eur J Pharm Sci 2009; 37(3-4): 300-305. https://dx.doi.org/10.1016/i.eips.2009.02.018.

105. Sun AX, Ye ZG, Li CY, Xue BY, Li LF, Cao XF, Yang Q, Dai BQ. Synergetic anticancer effects of tetrandrine combined with doxorubicin or vincristine in vitro. Zhongguo Yao Li Xue Bao 1999; 20(1): 69-73. https://www.ncbi.nlm.nih.gov/pubmed/10437129.

106. Buxhofer-Ausch V, Secky L, Wlcek K, Svoboda M, Kounnis V, Briasoulis $E$, et al. Tumor-specific expression of organic anion-transporting polypeptides: transporters as novel targets for cancer therapy. J Drug Deliv 2013; 2013: 863539. https://dx.doi.org/10.1155/2013/863539.

107. Lübbe AS, Alexiou C, Bergemann C. Clinical Applications of magnetic drug targeting. J Surg Res 2001; 95(2): 200-206. https://dx.doi.org/10.1006/jsre.2000.6030.

108. Laurencin M, Cam N, Georgelin T, Clément O, Autret G, Siaugue J-M, et al. Human erythrocytes covered with magnetic core-shell nanoparticles for multimodal imaging. Adv Healthc Mater 2013; 2(9): 1209-1212. https://dx.doi.org/10.1002/adhm.201200384.

109. Veiseh O, Sun C, Fang C, Bhattarai N, Gunn J, Kievit F, et al. Specific targeting of brain tumors with an optical/magnetic resonance imaging nanoprobe across the blood-brain barrier. Cancer Res 2009; 69(15): 6200-6207. https://dx.doi.org/10.1158/0008-5472.CAN-09-1157.

110. Dürr S, Janko C, Lyer S, Tripal P, Schwarz M, Zaloga J, et al. Magnetic nanoparticles for cancer therapy. Nanotechnol Rev 2013; 2(4): 395409. https://dx.doi.org/10.1515/ntrev-2013-0011.

111. Dandamudi S, Campbell RB. The drug loading, cytotoxicty and tumor vascular targeting characteristics of magnetite in magnetic drug targeting. Biomaterials 2007; 28(31): 4673-4683. https://dx.doi.org/10.1016/j.biomaterials.2007.07.024.

112. Dandamudi S, Patil V, Fowle W, Khaw B-A, Campbell RB. External magnet improves antitumor effect of vinblastine and the suppression of metastasis. Cancer Sci 2009; 100(8): 1537-1543. https://dx.doi.org/10.1111/i.1349-7006.2009.01201.x.

113. Zaffaroni N, Fiorentini G, De Giorgi U. Hyperthermia and hypoxia: new developments in anticancer chemotherapy. Eur J Surg Oncol 2001; 27(4): 340-342. https://dx.doi.org/10.1053/ejso.2000.1040.

114. Widder KJ, Senyei AE, Scarpelli DG. Magnetic microspheres: a model system for site-specific drug delivery in vivo. Exp Biol Med 1978; 158(2): 141-146. https://dx.doi.org/10.3181/00379727-158-40158.

115. Yatvin M, Weinstein J, Dennis W, Blumenthal R. Design of liposomes for enhanced local release of drugs by hyperthermia. Science 1978; 202(4374): 1290-1293. https://dx.doi.org/10.1126/science.364652.

116. Zubarev A., Abu-Bakr AF. Hyperthermia effect produced by interacting magnetic nanoparticles. In: 16-th International Plyos Conference on Nanodispersed Magnetic Fluids. Ivanovo, Russia: Ivanovo State Energy University, 2014: 312-315. http://ispu.ru/files/Sbornik po MZh 2014zap.pdf.

117. Andronescu E, Ficai M, Voicu G, Ficai D, Maganu M, Ficai A. Synthesis and characterization of collagen/hydroxyapatite: magnetite composite material for bone cancer treatment. J Mater Sci Mater Med 2010; 21(7): 2237-2242. https://dx.doi.org/10.1007/s10856-010-4076-7.

118. Guo X, Szoka FC. Steric stabilization of fusogenic liposomes by a lowph sensitive peg-diortho ester-lipid conjugate. Bioconjug Chem 2001; 12(2): 291-300. https://dx.doi.org/10.1021/bc000110v.

119. Shanta Singh N, Kulkarni H, Pradhan L, Bahadur D. A multifunctional biphasic suspension of mesoporous silica encapsulated with YVO4:Eu3+ and Fe304 nanoparticles: synergistic effect towards cancer therapy and imaging. Nanotechnology 2013; 24(6): 65101. https://dx.doi.org/10.1088/0957-4484/24/6/065101.

120. Batyrbekov EO, Rhakhimaeva DZ, Akylbekova TN. Sustained release of vincristine from microparticles of calcium alginate gel. Journal of Scientific and Technical Society "Kakhak" 2010; (2): 8-11. http://elibrary.kz/download/zhurnal st/st209.pdf.

121. Chen J, Li S, Shen Q. Folic acid and cell-penetrating peptide conjugated PLGA-PEG bifunctional nanoparticles for vincristine sulfate delivery. Eur J Pharm Sci 2012; 47(2): 430-443. https://dx.doi.org/10.1016/j.ejps.2012.07.002.

122. Ling G, Zhang $P$, Zhang W, Sun J, Meng $X$, Qin $Y$, et al. Development of novel self-assembled DS-PLGA hybrid nanoparticles for improving oral bioavailability of vincristine sulfate by P-gp inhibition. J Control Release 2010; 148(2): 241-248. https://dx.doi.org/10.1016/j.jconrel.2010.08.010.

123. Cui J, Li C, Wang C, Li Y, Zhang L, Zhang L, et al. Development of Pegylated Liposomal Vincristine Using Novel Sulfobutyl Ether Cyclodextrin Gradient: Is Improved Drug Retention Sufficient to Surpass DSPE-PEG-Induced Drug Leakage? J Pharm Sci 2011; 100(7): 2835-2848. https://dx.doi.org/10.1002/ips.22496.

124. Zucker D, Andriyanov AV, Steiner A, Raviv U, Barenholz Y. Characterization of PEGylated nanoliposomes co-remotely loaded with topotecan and vincristine: Relating structure and pharmacokinetics to therapeutic efficacy. J Control Release 2012; 160(2): 281-289. https://dx.doi.org/10.1016/j.jconrel.2011.10.003.

125. Leonetti C, Scarsella M, Semple SC, Molinari A, D’Angelo C, Stoppacciaro $A$, et al. In vivo administration of liposomal vincristine sensitizes drug-resistant human solid tumors. Int J Cancer 2004; 110(5): 767-774. https://dx.doi.org/10.1002/ijc.20174.

126. Wong MY, Chiu GNC. Liposome formulation of co-encapsulated vincristine and quercetin enhanced antitumor activity in a trastuzumab-insensitive breast tumor xenograft model. Nanomedicine 2011; 7(6): 834-840. https://dx.doi.org/:10.1016/j.nano.2011.02.001.

127. Stathopoulos GP, Antoniou D, Dimitroulis J, Stathopoulos J, Marosis K, Michalopoulou P. Comparison of liposomal cisplatin versus cisplatin in non-squamous cell non-small-cell lung cancer. Cancer Chemother 
Pharmacol 2011; 68(4): 945-950. https://dx.doi.org/10.1007/s00280011-1572-5.

128. Stathopoulos GP, Boulikas T. Lipoplatin formulation review article. J Drug Deliv 2012; 2012: 1-10. https://dx.doi.org/10.1155/2012/581363.

129. Zhang L, Gao H, Chen L, Wu B, Zheng Y, Liao R, et al. Tumor targeting of vincristine by mBAFF-modified PEG liposomes in B lymphoma cells. Cancer Lett 2008; 269(1): 26-36. https://dx.doi.org/10.1016/j.canlet.2008.04.024.

130. Tuscano JM, Martin SM, Ma Y, Zamboni W, O'Donnell RT. Efficacy, biodistribution, and pharmacokinetics of CD22-targeted pegylated liposomal doxorubicin in a B-cell non-Hodgkin's lymphoma xenograft mouse model. Clin Cancer Res 2010; 16(10): 2760-2768. https://dx.doi.org/10.1158/1078-0432.CCR-09-3199.

131. Zhang $T$, Zheng $Y$, Peng $Q$, Cao $X$, Gong $T$, Zhang $Z$. A novel submicron emulsion system loaded with vincristine-oleic acid ion-pair complex with improved anticancer effect: In vitro and in vivo studies. Int J Nanomedicine 2013; 8: 1185-1196. https://doi.org/10.2147/IJN.S41775.

132. Mathew ME, Mohan JC, Manzoor K, Nair SV, Tamura H, Jayakumar R. Folate conjugated carboxymethyl chitosan-manganese doped zinc sulphide nanoparticles for targeted drug delivery and imaging of cancer cells. Carbohydr Polym 2010; 80(2): 442-448. https://dx.doi.org/10.1016/j.carbpol.2009.11.047.

133. Savla R, Taratula O, Garbuzenko O, Minko T. Tumor targeted quantum dot-mucin 1 aptamer-doxorubicin conjugate for imaging and treatment of cancer. J Control Release 2011; 153(1): 16-22. https://dx.doi.org/10.1016/i.jconrel.2011.02.015.

134. Šírová M, Strohalm J, Chytil P, Lidický O, Tomala J, Říhová B, et al. The structure of polymer carriers controls the efficacy of the experimental combination treatment of tumors with HPMA copolymer conjugates carrying doxorubicin and docetaxel. J Control Release 2017; 246: 1-11. https://dx.doi.org/10.1016/j.jconrel.2016.12.004.

Authors:

Halahakoon Mudiyanselage Amila Jeewantha - PhD student, Department of Pharmaceutical Chemistry and Pharmaceutical Technology, Voronezh state University, Voronezh, Russia. http://orcid.org/0000-0002-4046-0859. 